Wiesław Konopka $a^{1,2}$

ORIGINAL PAPER

\author{
Małgorzata Pawlaczyk-Łuszczyńska
}

Mariola Śliwińska-Kowalska ${ }^{4}$

\title{
THE INFLUENCE OF JET ENGINE NOISE ON HEARING OF TECHNICAL STAFF
}

\section{WPŁYW HAŁASU SILNIKÓW ODRZUTOWYCH NA SŁUCH PERSONELU TECHNICZNEGO}

\author{
${ }^{1}$ Polish Mother's Memorial Hospital-Research Institute / Instytut Centrum Zdrowia Matki Polki, Łódź, Poland \\ Department of Otolaryngology / Klinika Otolaryngologii \\ ${ }^{2}$ Medical University of Lodz / Uniwersytet Medyczny w Łodzi, Łódź, Poland \\ Department of Didactics in Pediatrics / Zakład Dydaktyki Pediatrycznej \\ ${ }^{3}$ Nofer Institute of Occupational Medicine / Instytut Medycyny Pracy im. prof. J. Nofera, Łódź, Poland \\ Department of Physical Hazards / Zakład Zagrożeń Fizycznych \\ ${ }^{4}$ Nofer Institute of Occupational Medicine / Instytut Medycyny Pracy im. prof. J. Nofera, Łódź, Poland \\ Clinic of Audiology and Phoniatrics / Klinika Audiologii i Foniatrii
}

\begin{abstract}
Background: Due to high sound pressure levels (SPLs), noise produced by jet planes may be harmful to hearing of people working in their proximity. The aim of this study was to assess the effects of exposure to jet engine noise on technical staff hearing. Material and Methods: The study comprised 60 men, aged 24-50 years, employed in army as technical staff and exposed to jet engine noise for 6-20 years. The control group were 50 non-noise exposed males, aged 25-51 years. Exposure to noise emitted by jet engines was evaluated. Pure-tone audiometry (PTA) and distortion product otoacoustic emissions (DPOAE) were recorded in both groups. Results: Jet engines emitted broadband noise with spectrum dominated by components in the frequency range $315-6300 \mathrm{~Hz}$ (1/3-octave bands). Maximum A-weighted SPL during tests reached values of approx. 120-130 dB. Consequently, engine-servicing personnel (even in the case of a single engine test) was exposed to noise (at A-weighted daily noise exposure level above $95 \mathrm{~dB}$ ) exceeding permissible levels. Averaged audiometric hearing threshold levels of technical staff were higher $(\leq 17 \mathrm{~dB} H \mathrm{HL}, \mathrm{p}<0.001)$ than in the control group. Similarly, the DPOAE amplitude was lower $(\leq 17 \mathrm{~dB}$ SPL, $\mathrm{p}<0.01)$ in the noise-exposed subjects compared to the non-exposed ones. Significant reduction of DPOAE levels was mainly noted for high frequencies $(3-6 \mathrm{kHz})$. Conclusions: Despite the usage of hearing protection devices, both PTA and DPOAE consistently showed poorer hearing in engine-servicing personnel vs. control group. Med Pr 2014;65(5):583-592
\end{abstract}

Key words: jet engine noise, hearing impairment, pure tone audiometry, distortion product otoacoustic emission, DPOAE

\section{STRESZCZENIE}

Wstęp: Hałas emitowany przez silniki odrzutowe ze względu na wysoki poziom dźwięku może być szkodliwy dla słuchu osób pracujących w ich sąsiedztwie. Celem pracy była ocena wpływu ekspozycji na hałas na stan słuchu techników obsługujących silniki odrzutowe. Materiał i metody: Badaniami objęto 60 mężczyzn w wieku 24-50 lat, zatrudnionych w wojsku i narażonych na hałas silników odrzutowych przez okres 6-20 lat. Grupę porównawczą stanowiło 50 mężczyzn w wieku 25-51 lat nienarażonych zawodowo na hałas. Oceniono ekspozycję na hałas emitowany przez silniki odrzutowe. Diagnostykę słuchu oparto na badaniu audiometrią tonalną i rejestracji emisji otoakustycznych produktów zniekształceń nieliniowych (distortion product otoacoustic emissions - DPOAE). Wyniki: Silniki odrzutowe emitowały hałas szerokopasmowy, w którym dominowały składowe z przedziału częstotliwości 315-6300 Hz (pasma 1/3-oktawowe). Maksymalny poziom dźwięku A w czasie testów osiągał 120-130 dB. W konsekwencji, nawet w przypadku pojedynczego testu, personel obsługujący silniki był narażony na hałas (dzienny poziom ekspozycji $\left(\mathrm{L}_{\mathrm{Ex}, 8 \mathrm{~h}}\right)>95 \mathrm{~dB}$ ) przekraczający wartości najwyższych dopuszczalnych natężeń hałasu w środowisku pracy. Progi słuchu w grupie techników obsługujących silniki odrzutowe były wyższe $(\leq 17 \mathrm{~dB}$ HL, p $<0.001)$ niż w grupie porównawczej. Amplituda emisji otoakustycznych DPOAE była również niższa $(\leq 17 \mathrm{~dB}$ SPL, p $<0,01) \mathrm{u}$ osób narażonych na hałas $\mathrm{w}$ porównaniu $\mathrm{z}$ nienarażonymi. Jej istotne statystycznie obniżenie stwierdzono głównie dla wysokich częstotliwości (3-6 kHz). Wnioski: Mimo stosowania ochronników słuchu zarówno wyniki audiometrii tonalnej, jak i DPOAE wskazywały na gorszy słuch u techników obsługujących silniki odrzutowe niż u osób z grupy porównawczej. Med. Pr. 2014;65(5):583-592

Słowa kluczowe: hałas silników odrzutowych, uszkodzenie słuchu, audiometria tonalna, emisja otoakustyczna produktów zniekształceń nieliniowych, DPOAE

Corresponding author / Autor do koresponencji: Wiesław Konopka, Polish Mother's Memorial Hospital-Research Institute, Department of Otolaryngology, Rzgowska 281/289, 93-338 Łódź, Poland, e-mail: wieslaw.konopka@umed.lodz.pl Received: 2013, October 2, accepted: 2014, April 16 


\section{INTRODUCTION}

Due to high sound pressure levels, noise emitted by jet planes may be harmful to hearing of people working in the immediate proximity of aircraft, i.e., pilots and technical staff. Furthermore, this kind of noise may be burdensome both for the environment and for communities living close to airports. Noise-induced hearing loss (NIHL) is usually irreversible by nature and can lead to early retirement of highly qualified aviation specialists. Technical staff members work directly by jet engines during take-off or technical tests in engine test houses. Furthermore, these employees can be also exposed to chemical agents, including Jet-A-1 turbineengine fuel which can be ototoxic. Combined exposures to ototoxins and noise have been shown to cause synergistic damage to the inner ear $(1,2)$.

Extremely high levels of noise emitted by jet engines may cause permanent hearing damage even after a single exposure (3). A specific feature of exposure to noise for a relatively short-time is the fact that noise with high sound intensity levels is on the borderline between the reversible and irreversible damage to the hair cells of the Corti organ (4).

Transient-evoked otoacoustic emission (TEOAE) and distortion-product otoacoustic emission (DPOAE) are non-invasive, objective and frequency-specific auditory tests for evaluating outer hair cell function. Since high intensity sounds predominantly damage the outer hair cells of the Corti organ, otoacoustic emission (OAE) seems to be the method of choice in monitoring harmful effect of noise on hearing $(3,5,6)$.

Tests on animals have revealed a strong correlation between frequency parameters of the stimulus applied and the actual location of the damaged area within the cochlea, which was later confirmed in a histological examination (7). The tests in question have confirmed the feasibility of using DPOAE as a highly sensitive method of monitoring the function of outer hair cells after exposure to noise $(8,9)$.

It has been shown that OAEs in humans and in animals are reduced after short exposures to noise and OAE measurements appear to be a sensitive method of monitoring early cochlear changes after noiseinduced trauma $(10,11)$. Moreover, OAE appears to be a more sensitive method than pure tone audiometry in monitoring early cochlear changes related to military and industrial exposures to noise $(1,11)$.

The aim of this study, a continuation of our previous investigation (1), was to assess the impact of exposure to jet engine noise on hearing, as assessed using pure tone audiometry (PTA) and distortion product otoacoustic emissions (DPOAE) in jet engine servicing personnel.

\section{MATERIAL AND METHODS}

\section{Study groups}

The study group comprised 60 men aged $24-50$ years (mean \pm standard deviation $(\mathrm{M} \pm \mathrm{SD})$ : $35.5 \pm 2.75)$ who were exposed to jet engine noise. The tested individuals worked in close vicinity of planes' jet engines and were exposed to noise both during assistance in take-off as well as in the course of engine-house tests. The period of exposure to jet noise ranged from 6 to 20 years ( $\mathrm{M} \pm \mathrm{SD}: 3.5 \pm 2.6$ for the whole group). All subjects used commonly available hearing protection devices (HPDs) such as the Peltor H10A, H9A, H7A, H6A or H3A earmuffs, replaced annually. Besides noise, they were occasionally exposed to chemicals (including Jet-A-1 turbineengine fuel) used in aircraft maintenance and service.

The control group comprised 50 male volunteers, aged $25-51$ years ( $\mathrm{M} \pm \mathrm{SD}: 36.2 \pm 3.25$ years), not occupationally exposed to noise, with normal hearing (hearing thresholds $\leq 20-30 \mathrm{~dB}$ HL at standard frequencies from 0.125 to $8 \mathrm{kHz}$ for both ears). Majority of them were army office workers. They did not differ by age, education or socioeconomic level from the study subjects exposed to jet engine noise.

In both groups, individuals with middle ear pathology were excluded based on otoscopy and tympanometry results. Furthermore, after a complementary questionnaire survey, subjects who regularly attended high-level noisy leisure activities (e.g., disco/dance bars, rock concerts, shooting, etc.) were also excluded.

The study protocol was approved by the Medical Ethical Committee of the Medical University of Lodz, Poland, and all subjects gave their written consent for participation in the examinations.

\section{Noise exposure evaluation}

Exposure to noise emitted by jet engines was evaluated from results of noise measurements which were described in detail in our earlier paper (1). Those measurements were carried out according to Standards No. PN-N-01307:1994 and PN-ISO 9612:2004 at a short distance from the TS-11 ISKRA jet planes during testing their engines $(12,13)$. The following noise parameters were determined:

A- and C-weighted equivalent-continuous sound pressure levels $\left(\mathrm{L}_{\mathrm{A} \text { eq, }, \mathrm{T}}, \mathrm{L}_{\mathrm{C} \text { eq, } \mathrm{T}}\right)$, 
maximum A-weighted sound pressure level with $\mathrm{S}$ (slow) time constant $\left(\mathrm{L}_{\mathrm{A} \text { max }}\right)$,

peak C-weighted sound pressure level $\left(\mathrm{L}_{\mathrm{C} \text { peak }}\right)$.

Additionally, frequency analysis in 1/3-octave bands in the frequency range from $10 \mathrm{~Hz}$ to $20000 \mathrm{~Hz}$ was performed.

A sampling technique using integrating-averaging sound level meters was applied. The duration of each measurement corresponded to the duration of a single test. For the sake of safety, microphone was positioned as close as practically possible (at a distance up to 0.5 ) to the technician's ears and approx. 1-1.5 $\mathrm{m}$ from the working engines.

\section{Pure-tone audiometry}

Conventional air-conduction pure-tone audiometry (PTA) was recorded for the frequency range from 0.125 to $8 \mathrm{kHz}$. Hearing levels were measured in each ear by a trained member of clinical staff. Sound level was systematically increased and decreased in steps of $5 \mathrm{~dB}$ to find the critical value (i.e., the threshold) that separated the audible from inaudible range (14) using a clinical audiometer (model OB 622; Madsen, Denmark). The audiometer was calibrated according to ISO $389(15,16)$ and validated each year. Impedance audiometry tests were performed in all subjects (using a Zodiac 901; Madsen, Denmark) and revealed tympanograms type A and normal acoustic reflexes.

\section{Otoacoustic emissions}

Otoacoustic emissions were recorded for each ear in a quiet room using an ILO 292 Echoport version 5.0. (Otodynamics Ltd). Distortion-product otoacoustic emission were recorded with DP-Gram procedure with the same probe by an ENT specialist. The 2f1-f2 DPOAE were recorded at a single level of $70-75 \mathrm{~dB}$ SPL. The $\mathrm{f} 2 / \mathrm{f} 1 \mathrm{ratio}$ was held constant at 1.22 . Spectral analysis of the microphone signal was based on 128 averages for primary frequencies below $1 \mathrm{kHz}$ and on 64 averages for higher frequencies. Averaging was used until the "noise floor" was stable. Recordings were made on Mondays after 2 days of an auditory rest.

\section{Data analysis}

For all of the investigated parameters, statistical significance of the difference between the 2 groups was evaluated using the Wilcoxon rank sum test. This is an equivalent of Student's t-test when distributions of the analyzed populations are not normal. Confidence level at $95 \%$ ( $\mathrm{p}<0.05)$ was chosen as the criterion of significance.

\section{RESULTS}

The tested jet engines emit broadband noise with spectrum dominated by components in the $315-6300 \mathrm{~Hz}$ (1/3-octave band) frequency range (Figure 1). Maximum A-weighted sound pressure levels reached values of approx. 119.7-130.1 dB. The C-weighted peak sound pressure levels ranged from 132.8 to $141.9 \mathrm{~dB}$. The equivalent-continuous A-weighted sound pressure level $\mathrm{L}_{\mathrm{A} \text { eq, } \mathrm{T}}$ (during single test lasting from 201 to $243 \mathrm{~s}$ ) varied from $109.4 \mathrm{~dB}$ to $119.7 \mathrm{~dB}$ which, in terms of the standard daily working time, corresponded to daily noise exposure level (normalized to a nominal 8-h working day - $\mathrm{L}_{\mathrm{EX}, \text { sh }}$ ) of $95.7 \mathrm{~dB}$. Greater number of tests during working day resulted in higher values of the $\mathrm{L}_{\mathrm{EX}, \text { sh }}$ level (up to $105.7 \mathrm{~dB}$ for 10 tests per day).

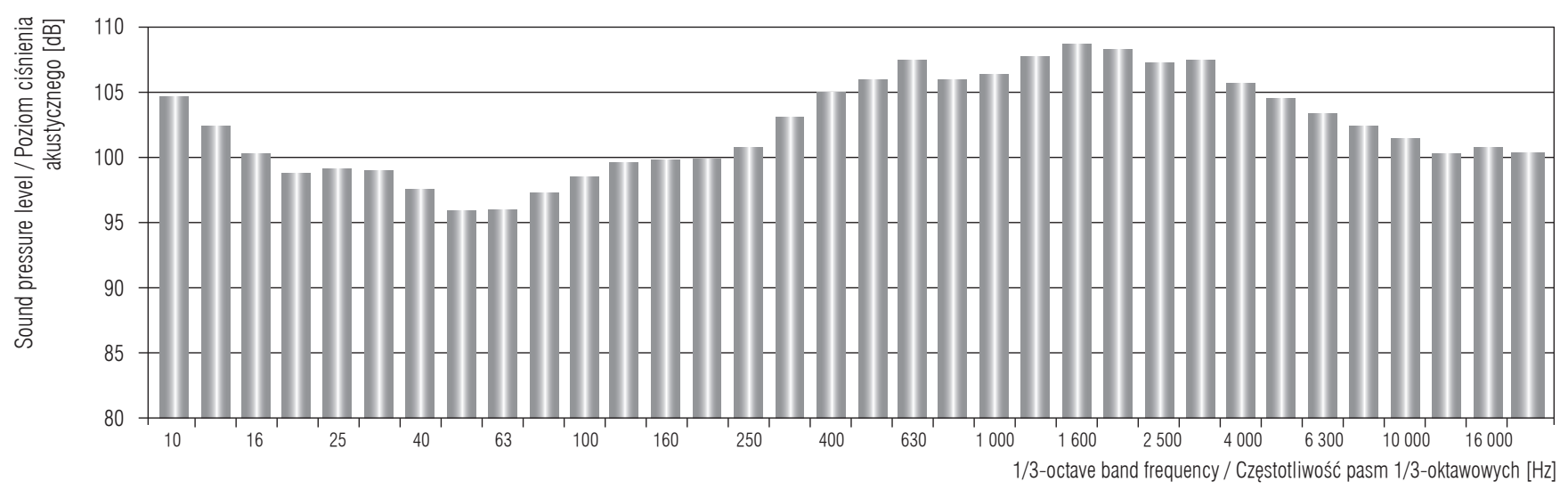

Fig. 1. Frequency spectrum of noise emitted by jet engines during tests (bars represent equivalent-continuous sound pressure levels in $1 / 3$-octave bands)

Ryc. 1. Widmo hałasu emitowanego przez silniki odrzutowe podczas testów (słupkami oznaczono wartości równoważne poziomu ciśnienia akustycznego w pasmach 1/3-oktawowych) 
Therefore, it was found that technicians participating in jet engine tests (even in the case of a single exposure) were exposed to noise exceeding the maximum admissible intensity (MAI) values for noise in the working environment (17) (Table 1).

The study subjects used commonly available earmuffs characterized by single noise reduction (SNR) values of $24-34 \mathrm{~dB}$. The predicted equivalent-continuous A-weighted sound pressure levels under the aforesaid HPDs, calculated according to PN-ISO 486:2006 recommendations (18), ranged from 82 to $91 \mathrm{~dB}$. Thus, hearing protection devices were able to significantly reduce (26-35 dB) the actual exposure to noise, provided that they had been properly applied.

Average pure tone audiometry values for the noiseexposed and control groups have been specified in Table 2. Statistical analysis comparing the average audiogram values for both groups revealed significant difference in right-ear results, except for the frequency of $2000 \mathrm{~Hz}$ ( $\mathrm{p}=0.238$ ). Statistically significant differences $(p<0.001)$ were also found for all frequencies in left ears (Table 2, Figure 2 and 3).

Table 1. Results of noise measurements during testing jet engines vs. Polish occupational exposure limit values (17)

Tabela 1. Wyniki pomiarów hałasu podczas testów silników odrzutowych vs wartości dopuszczalne dla ekspozycji zawodowej na hałas obowiązujące w Polsce (17)

\begin{tabular}{|c|c|c|}
\hline \multirow[b]{2}{*}{$\begin{array}{l}\text { Parameter } \\
\text { Parametr }\end{array}$} & \multicolumn{2}{|c|}{$\begin{array}{l}\text { Noise } \\
\text { Hałas }\end{array}$} \\
\hline & $\begin{array}{l}\text { measurement } \\
\text { pomiar }\end{array}$ & $\begin{array}{c}\text { MAI } \\
\text { NDN } \\
(17)\end{array}$ \\
\hline Equivalent-continuous A-weighted sound pressure level / Równoważny poziom dźwięku A ( $\mathrm{L}_{\mathrm{A} \mathrm{eq,}}$ ) [dB] & $\begin{array}{c}109.4-119.7 \\
116.8^{*}\end{array}$ & - \\
\hline $\begin{array}{l}\text { Noise exposure level normalized to a nominal } 8 \mathrm{~h} \text { working day / Poziom ekspozycji na hałas odniesiony } \\
\text { do 8-godzinnego dobowego wymiaru czasu pracy }\left(\mathrm{L}_{\mathrm{EX}, 8 \mathrm{~h}}\right)[\mathrm{dB}]\end{array}$ & $95.7^{* *}$ & 85 \\
\hline Maximum A-weighted sound pressure level / Maksymalny poziom dźwięku A $\left(\mathrm{L}_{\mathrm{A} \max }\right)[\mathrm{dB}]$ & $119.7-130.1$ & 115 \\
\hline C-weighted peak sound pressure level / Szczytowy poziom dźwięku C $\left(\mathrm{L}_{\mathrm{C} \text { peak }}\right)[\mathrm{dB}]$ & $132.9-141.9$ & 135 \\
\hline
\end{tabular}

MAI - maximum admissible intensity values for noise in the work environment (17) / NDN - najwyższe dopuszczalne natężenie hałasu w środowisku pracy.

* Energy average / Średnia energetyczna.

** Daily noise exposure level corresponding to a single test of jet engines per an 8-hour working day / Dzienny poziom ekspozycji na hałas odpowiadający pojedynczemu testowi silników odrzutowych w ciągu 8-godzinnego dnia pracy.

*** Arithmetic average / Średnia arytmetyczna.

Table 2. Results of pure tone audiometry (PTA) in the noise-exposed and control groups ${ }^{\mathrm{a}}$

Tabela 2. Wyniki audiometrii tonalnej w grupie narażonej na hałas i porównawczeja

\begin{tabular}{|c|c|c|c|c|}
\hline \multirow{3}{*}{$\begin{array}{c}\text { Frequency } \\
\text { Częstotliwość } \\
{[\mathrm{Hz}]}\end{array}$} & \multicolumn{4}{|c|}{$\begin{array}{l}\text { Hearing threshold level } \\
\text { Próg słuchu } \\
(\mathrm{M} \pm \mathrm{SD}) \\
{[\mathrm{dB} \mathrm{HL}]}\end{array}$} \\
\hline & \multicolumn{2}{|c|}{$\begin{array}{l}\text { noise-exposed group } \\
\text { grupa narażona na hałas } \\
(\mathrm{N}=60)\end{array}$} & \multicolumn{2}{|c|}{$\begin{array}{l}\text { control group } \\
\text { grupa porównawcza } \\
(\mathrm{N}=50)\end{array}$} \\
\hline & $\begin{array}{c}\text { right ear } \\
\text { ucho prawe }\end{array}$ & $\begin{array}{c}\text { left ear } \\
\text { ucho lewe }\end{array}$ & $\begin{array}{l}\text { right ear } \\
\text { ucho prawe }\end{array}$ & $\begin{array}{c}\text { left ear } \\
\text { ucho lewe }\end{array}$ \\
\hline 125 & $15.0 \pm 0.8$ & $14.0 \pm 1.1$ & $10.0 \pm 0.7$ & $11.0 \pm 0.9$ \\
\hline 250 & $20.0 \pm 2.1$ & $15.0 \pm 1.8$ & $14.0 \pm 1.5$ & $10.0 \pm 0.8$ \\
\hline 500 & $19.0 \pm 2.0$ & $17.5 \pm 1.8$ & $12.0 \pm 1.1$ & $11.0 \pm 0.7$ \\
\hline 1000 & $19.0 \pm 2.4$ & $15.0 \pm 1.9$ & $14.0 \pm 1.2$ & $12.0 \pm 0.9$ \\
\hline 2000 & $16.0 \pm 3.0^{*}$ & $15.5 \pm 1.9$ & $15.0 \pm 1.0$ & $11.0 \pm 1.9$ \\
\hline
\end{tabular}


Table 2. Results of pure tone audiometry (PTA) in the noise-exposed and control groups ${ }^{\mathrm{a}}-$ cont. $^{\circ}$

Tabela 2. Wyniki audiometrii tonalnej w grupie narażonej na hałas i porównawczej ${ }^{\mathrm{a}}-\mathrm{cd}$.

\begin{tabular}{|c|c|c|c|c|}
\hline \multirow{2}{*}{$\begin{array}{c}\text { Frequency } \\
\text { Częstotliwość } \\
{[\mathrm{Hz}]}\end{array}$} & \multicolumn{4}{|c|}{$\begin{array}{l}\text { Hearing threshold level } \\
\text { Próg słuchu } \\
(\mathrm{M} \pm \mathrm{SD}) \\
{[\mathrm{dB} \mathrm{HL}]}\end{array}$} \\
\hline & \multicolumn{2}{|c|}{$\begin{array}{l}\text { noise-exposed group } \\
\text { grupa narażona na hałas } \\
\qquad(\mathrm{N}=60)\end{array}$} & \multicolumn{2}{|c|}{$\begin{array}{l}\text { control group } \\
\text { grupa porównawcza } \\
(\mathrm{N}=50)\end{array}$} \\
\hline 3000 & $20.0 \pm 2.0$ & $21.5 \pm 1.8$ & $15.0 \pm 1.6$ & $11.0 \pm 1.2$ \\
\hline 4000 & $25.5 \pm 2.9$ & $27.0 \pm 3.1$ & $15.0 \pm 2.0$ & $12.0 \pm 2.1$ \\
\hline 6000 & $30.0 \pm 3.4$ & $30.0 \pm 3.8$ & $20.0 \pm 2.4$ & $13.0 \pm 2.7$ \\
\hline 8000 & $12.0 \pm 2.3$ & $21.5 \pm 3.8$ & $15.0 \pm 1.3$ & $14.0 \pm 1.5$ \\
\hline
\end{tabular}

a Significant differences between groups were noted for most cases, p < 0.001 / Różnice między grupami istotne statystycznie stwierdzono w większości przypadków, p $<0,001$. $\mathrm{M}$ - mean / średnia, SD - standard deviation / odchylenie standardowe.

* No significant difference between the noise-exposed and control groups $(\mathrm{p}=0.238) /{ }^{*}$ Brak istotnej statystycznie różnicy między grupą narażoną na hałas a grupą porównawczą $(\mathrm{p}=0.238)$.

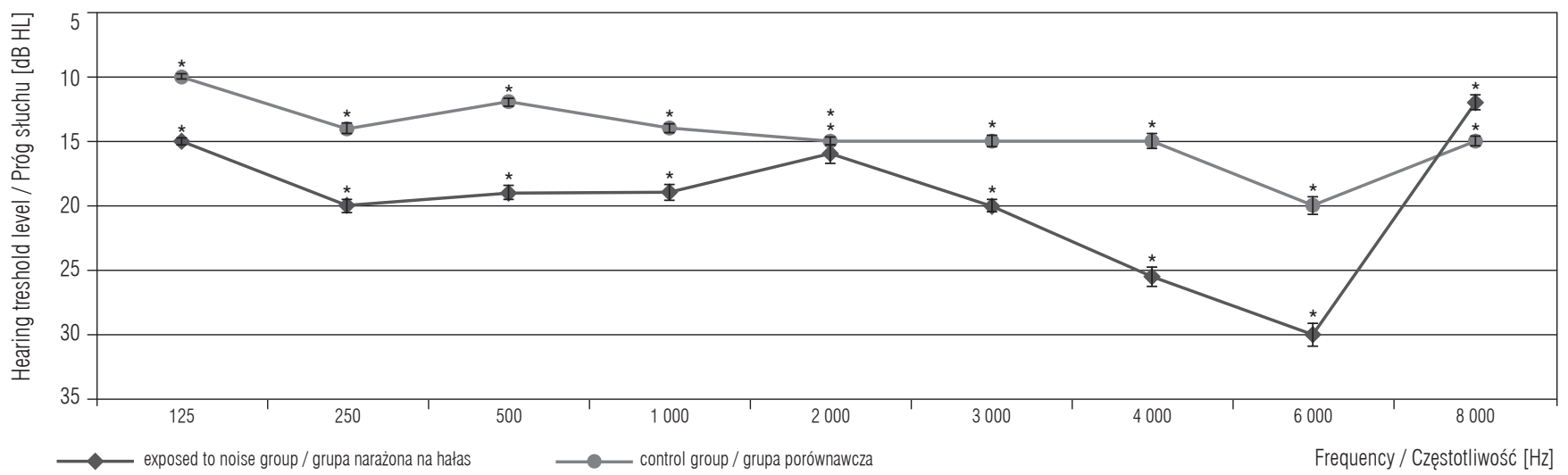

*A significant difference / Różnica istotna statystycznie $(\mathrm{p}<0.001)$.

Fig. 2. Audiometric hearing threshold levels in the noise-exposed and control groups - right ear (mean values $\pm 95 \%$ confidence intervals) Ryc. 2. Audiometryczne progi słuchu w grupie narażonej na hałas i grupie porównawczej - ucho prawe (wartości średnie \pm 95 -procentowy przedział ufności)

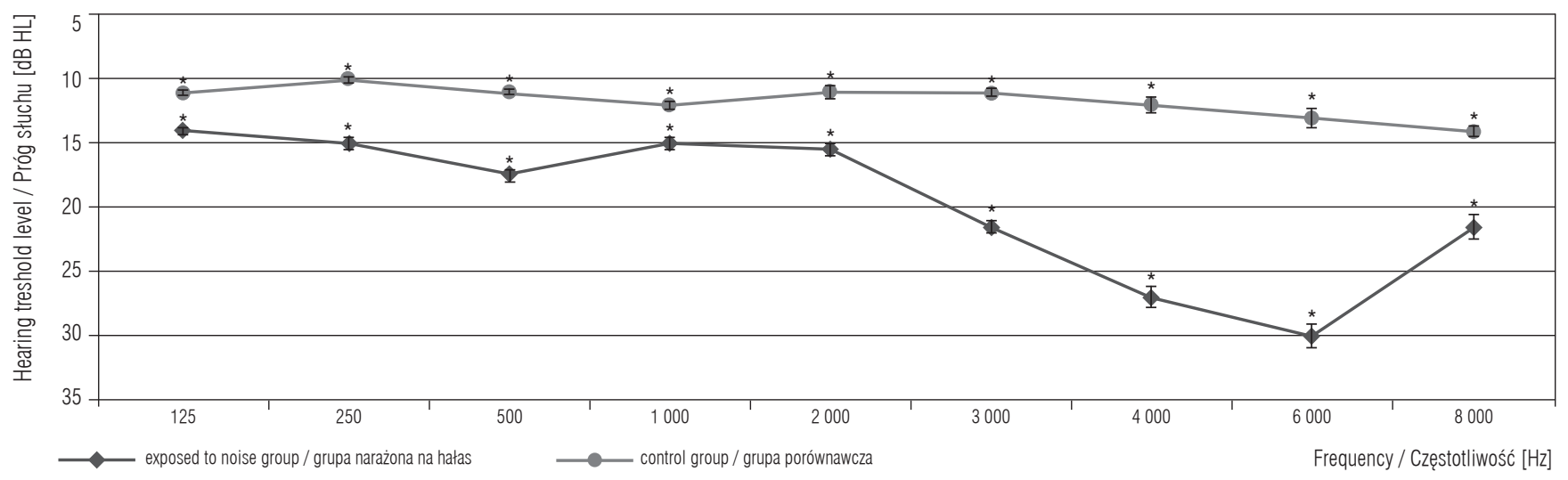

* A significant difference / Różnica istotna statystycznie $(\mathrm{p}<0.001)$.

Fig. 3. Audiometric hearing threshold levels in the noise-exposed and control groups - left ear (mean values $\pm 95 \%$ confidence intervals) Ryc. 3. Audiometryczne progi słuchu w grupie narażonej na hałas i grupie porównawczej - ucho lewe (wartości średnie \pm 95-procentowy przedział ufności) 
Comparison of mean PTAs between the exposed and the control groups revealed the largest differences for $4 \mathrm{kHz}$ and $6 \mathrm{kHz}$, equal to 10.5 and $10 \mathrm{~dB}$ for the right ear, and 15 and $17 \mathrm{~dB}$ for the left ear, respectively.
Results of the DPOAE testing have been summarized in Table 3. It is worth to highlight that, in both groups, signal to noise ratio $(\mathrm{S} / \mathrm{N})$ was $>6 \mathrm{~dB}$ for $95 \%$ of ears at all of the frequencies, except for the lowest

Table 3. Results of DPOAE registered in the noise-exposed and control groups

Tabela 3. Wyniki zarejestrowanej DPOAE w grupie narażonej na hałas i porównawczej

\begin{tabular}{|c|c|c|c|c|}
\hline \multirow{2}{*}{$\begin{array}{c}\text { Frequency } \\
\text { Częstotliwość } \\
{[\mathrm{Hz}]}\end{array}$} & \multicolumn{2}{|c|}{$\begin{array}{l}\text { Noise-exposed group } \\
\text { Grupa narażona na hałas } \\
(\mathrm{N}=60) \\
(\mathrm{M} \pm \mathrm{SD})\end{array}$} & \multicolumn{2}{|c|}{$\begin{array}{c}\text { Control group } \\
\text { Grupa porównawcza } \\
(\mathrm{N}=50) \\
(\mathrm{M} \pm \mathrm{SD})\end{array}$} \\
\hline & $\begin{array}{l}\text { amplitude of DPOAE } \\
\text { amplituda DPOAE } \\
\text { [dB SPL] }\end{array}$ & $\begin{array}{l}\mathrm{S} / \mathrm{N} \\
{[\mathrm{dB}]}\end{array}$ & $\begin{array}{l}\text { amplitude of DPOAE } \\
\text { amplituda DPOAE } \\
\text { [dB SPL] }\end{array}$ & $\begin{array}{l}\mathrm{S} / \mathrm{N} \\
{[\mathrm{dB}]}\end{array}$ \\
\hline \multicolumn{5}{|l|}{ Right ear / Ucho prawe } \\
\hline 1001 & $5.60 \pm 4.51$ & $11.92 \pm 5.24$ & $6.31 \pm 5.76$ & $15.99 \pm 6.31$ \\
\hline 1501 & $9.99 \pm 6.78$ & $22.37 \pm 7.64$ & $12.24 \pm 7.57$ & $26.10 \pm 8.15$ \\
\hline 2002 & $6.35 \pm 5.73$ & $15.64 \pm 5.3$ & $9.19 \pm 6.79$ & $22.34 \pm 7.62$ \\
\hline 3003 & $-1.73 \pm 6.08^{*}$ & $3.11 \pm 8.37$ & $7.63 \pm 5.35^{*}$ & $16.53 \pm 8.78$ \\
\hline 4004 & $-2.52 \pm 8.62^{*}$ & $11.35 \pm 8.58$ & $8.54 \pm 6.14^{\star}$ & $14.37 \pm 8.32$ \\
\hline 5005 & $7.57 \pm 7.83^{*}$ & $19.70 \pm 9.1$ & $17.13 \pm 8.23^{*}$ & $18.90 \pm 9.12$ \\
\hline 6006 & $4.99 \pm 7.02^{*}$ & $20.99 \pm 7.13$ & $14.98 \pm 6.82^{*}$ & $19.79 \pm 6.76$ \\
\hline \multicolumn{5}{|l|}{ Left ear / Ucho lewe } \\
\hline 1001 & $5.56 \pm 5.05$ & $16.31 \pm 6.21$ & $5.63 \pm 5.30$ & $16.62 \pm 7.16$ \\
\hline 1501 & $5.85 \pm 6.04^{*}$ & $14.21 \pm 5.26$ & $11.03 \pm 4.71^{*}$ & $24.69 \pm 5.26$ \\
\hline 2002 & $3.53 \pm 5.07^{*}$ & $16.06 \pm 6.54$ & $9.46 \pm 6.73^{*}$ & $21.36 \pm 7.45$ \\
\hline 3003 & $-1.95 \pm 10.04^{*}$ & $9.75 \pm 11.57$ & $8.04 \pm 4.69^{*}$ & $18.14 \pm 6.01$ \\
\hline 4004 & $0.36 \pm 7.61^{*}$ & $8.01 \pm 6.26$ & $10.02 \pm 4.65^{\star}$ & $23.89 \pm 5.37$ \\
\hline 5005 & $4.29 \pm 6.02^{\star}$ & $20.99 \pm 7.13$ & $17.87 \pm 5.76^{*}$ & $15.67 \pm 7.26$ \\
\hline 6006 & $-0.50 \pm 6.75^{\star}$ & $13.71 \pm 6.24$ & $16.38 \pm 5.48^{*}$ & $16.99 \pm 5.49$ \\
\hline
\end{tabular}

DPOAE - distortion product otoacoustic emissions / emisja otoakustycznych produktów zniekształceń nieliniowych, S/N - signal to noise ratio / stosunek sygnału do szumu. Other abbreviations as in Table 2 / Pozostałe skróty jak w tabeli 2.

* Significant differences between the noise-exposed and control groups $(\mathrm{p}<0.01) /$ Istotne statystycznie różnice między grupą narażoną na hałas a grupą porównawczą ( $\mathrm{p}<0,01)$.

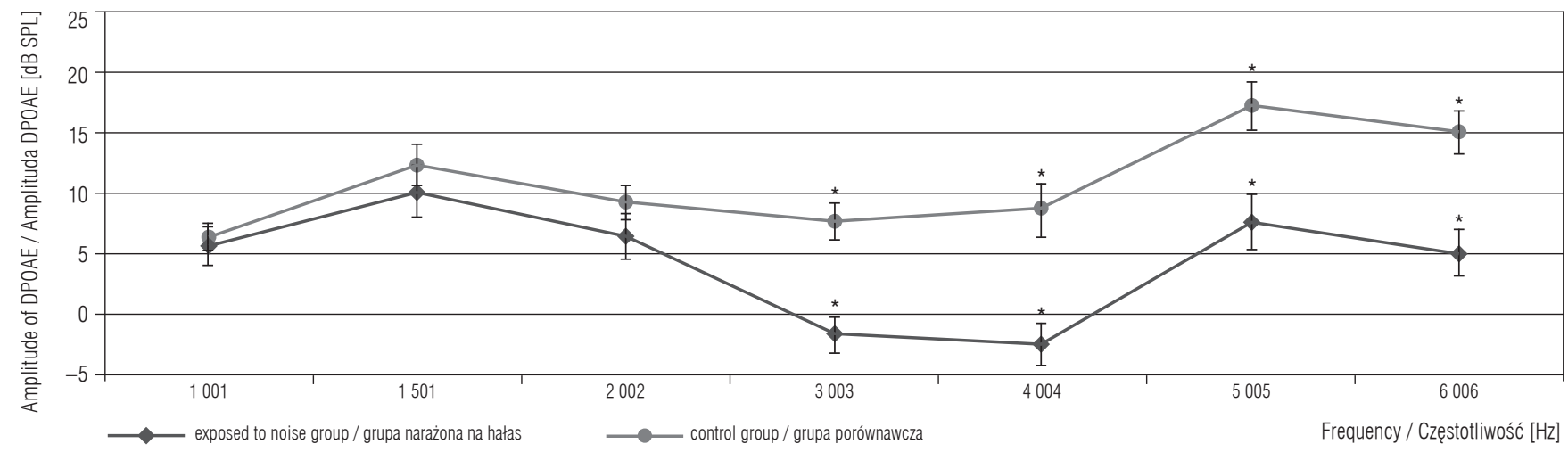

DPOAE - distortion product otoacoustic emissions / emisja otoakustycznych produktów zniekształceń nieliniowych.

* A significant difference / Różnica istotna statystycznie $(\mathrm{p}<0.01)$

Fig. 4. Amplitude of DPOAE in the noise-exposed and control groups - right ear (mean values $\pm 95 \%$ confidence intervals) Ryc. 4. Amplituda DPOAE w grupie narażonej na hałas i grupie porównawczej - ucho prawe (wartości średnie \pm 95-procentowy przedział ufności) 


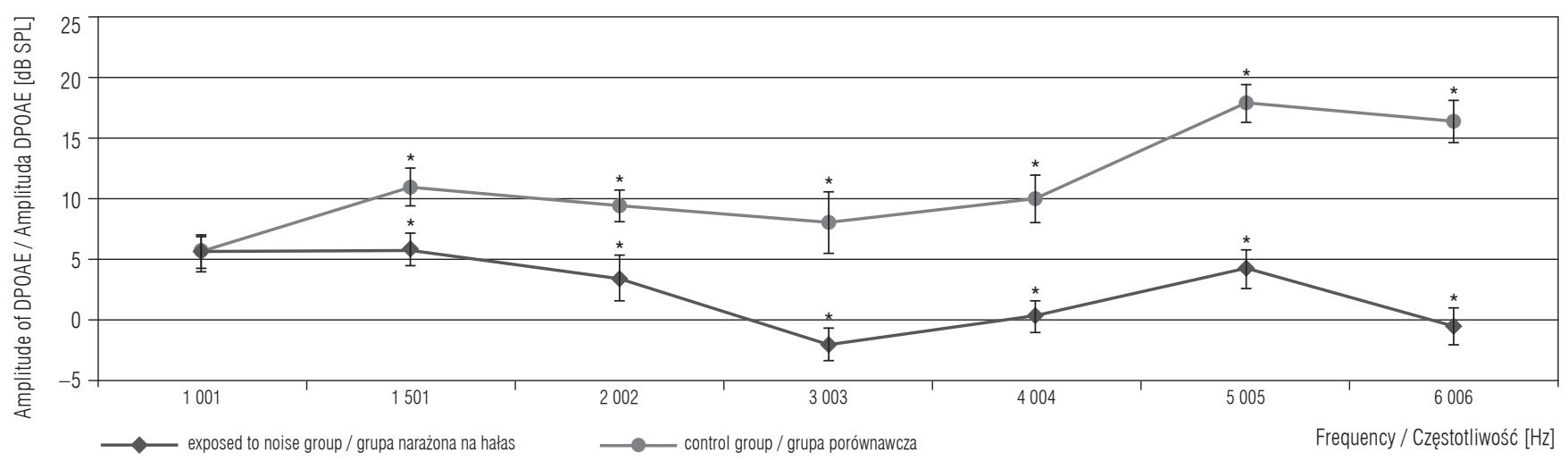

DPOAE - distortion product otoacoustic emissions / emisja otoakustycznych produktów zniekształceń nieliniowych.

* A significant difference / Różnica istotna statystycznie $(\mathrm{p}<0.01)$.

Fig. 5. Amplitude of DPOAE in the noise-exposed and control groups - left ear (mean values $\pm 95 \%$ confidence intervals) Ryc. 5. Amplituda DPOAE w grupie narażonej na hałas i grupie porównawczej - ucho lewe (wartości średnie \pm 95-procentowy przedział ufności)

frequency $(0.8 \mathrm{kHz})$. However, as expected, the records of DPOAE in the technical staff group showed much lower DPOAE values in comparison with the control group. Reduction in the DPOAE value was recorded in the right and left ear, and was greatest for the frequencies of $3,4,5$ and $6 \mathrm{kHz}(\mathrm{p}<0.01)$. The DPOAE amplitude reduction at $3,4,5$ and $6 \mathrm{kHz}$ was 9.99 , 9.66, 13.58 and $16.88 \mathrm{~dB}$ SPL, respectively, for the left ear (Table 3 ). The greatest right-ear reduction was noted at 3, 4, 5 and $6 \mathrm{kHz}$, and reached 9.36, 11.06, 9.56 and $9.99 \mathrm{~dB}$ SPL respectively (Table 3, Figure 4 and 5).

\section{DISCUSSION}

Noise-induced hearing loss is one of the most common instances of hearing impairment and, at present, there is no effective treatment for its recovery. Initially, the damage may take a reversible, temporary form, i.e., a temporary threshold shift (TTS). However, further exposure leads to a permanent threshold shift (PTS). The degree and type of hypoacusis is determined by multiple factors, both environmental and intrinsic, including type of noise (impulse noise in more harmful than steady-state noise), time of exposure, co-exposure to chemicals, age, smoking, hyperlipidemia, and hereditary factors (19).

In this study, exposure to noise of the technicians servicing jet engines was evaluated and their hearing functionality was assessed using pure tone audiometry and distortion product otoaocustic emission.

According to our evaluation, the study subjects were exposed to noise at levels $\left(\mathrm{L}_{\mathrm{EX}, 8 \mathrm{~h}}>95 \mathrm{~dB}\right)$ greatly exceeding the Polish MAI values for the working environment (17). Moreover, overexposure to noise took place even in the case of a single test of jet engine. Noise spectrum was dominated by components in the frequency range of 315-6300 Hz (1/3-octave bands).

Technical staff servicing jet engines was subjected to short-term noise. Impulse noise and short-term noise are believed to be especially dangerous for hearing, because the defensive mechanisms of the hearing organ have certain inertia that needs time to activate. Moreover, it has been shown that hearing damage caused by exposure to short-term noise depends on the peak sound pressure level $(20,21)$.

Pure-tone audiometry is commonly approved as the golden standard of hearing functionality assessment in subjects exposed to noise. Results of our study show that hearing thresholds were significantly poorer in the group exposed to jet noise as compared to non-exposed controls. Not surprisingly, differences were largest at high audiometric frequencies, as it is known that hearing at $4-6 \mathrm{kHz}$ is the most vulnerable to broadband noise. Hearing impairment in the case of technicians servicing jet engines was significant even though a great majority of them used hearing protection devices. It indicates that hearing conservation program in this staff group is not satisfactory, and monitoring early changes in the auditory organ should be rigorously obeyed.

Since PTA may fail to detect early signs of cochlear damage caused by noise, applicability of other procedures for screening and monitoring of NIHL was tested. In particular, OAEs have been proposed as a sensitive method of monitoring early cochlear changes after 
noise-induced trauma (10). Therefore, in this study, the impact of exposure to jet engine noise on technical staff hearing was evaluated using both PTA and DPOAEs.

Just like PTA tests, results of this study indicated that the amplitude of DPOAE was reduced mainly at high frequencies. It is in agreement with previous research. For example in an earlier study, Jędrzejczak et al. (20) presented comparative results of TEOAE analysis carried out in a group of individuals exposed to jet engine noise and non-exposed group, using a matching pursuit (MP) algorithm. According to the aforesaid study, TEOAE amplitudes of the exposed group are significantly smaller and fall monotonically in the range from $100 \mu \mathrm{Pa}$ to $50 \mu \mathrm{Pa}$ (14-8 dB SPL). TEOAE amplitudes of the healthy group are above the level of $100 \mu \mathrm{Pa}$ (14 dB SPL) in all of the half-octave bands (20).

In this study, the difference in DPOAE response between non-exposed subjects and those exposed to jet engine noise grows with frequency (Table 3), which is consistent with the fact that parts of the cochlea responding to higher frequencies are more fragile. Moreover, the frequencies with amplitudes shown to be reduced in DPOAE results were similar to the dominant frequency bands of noise emitted by jet engines. This may indicate significant impact not only by high peak pressure levels but also by frequency band emitted by jet engine noise which can damage the organ of Corti.

Otoacoustic emissions have been proposed as a useful tool of monitoring NIHL. Lapsley Miller et al. noticed that hearing thresholds increased by $1.2 \mathrm{~dB}$ and the DPOAE amplitude decreased by $-0.9 \mathrm{~dB}(22)$ in the noise-exposed group. Results of a study by Subramaniam et al. (23) indicated that, after interrupted noise exposure, changes in the DPOAE amplitude paralleled recovery in the amplitude and the threshold of the compound action potentials (23). Eddins et al. reported that continuous exposure to octave-band noise in chinchillas caused a reduction in DPOAE amplitude that was greatest at $\mathrm{f} 2$ frequencies within and above 3, 4, 6 and $8 \mathrm{kHz}$ (24). Tests of the influence of noise on the cochlea revealed a strong correlation between frequency parameters of the stimulus applied and the actual location of the damaged area within the cochlea, which was later confirmed in a histological examination $(7,24)$. The tests in question have confirmed the DPOAE as a highly-sensitive method to monitor the function of outer hair cells after exposure to noise $(10,25)$.

Basing on our own findings and data from the relevant literature, OAE may be classified as a highly valuable and sensitive method, especially in terms of evaluating extremely early damage to the cochlea, often undetectable by other methods of examination. Davis et al. recommended DPOAE in the evaluation of hearing and sensory cell loss in noise-damaged cochleas. In noise-exposed chinchillas, post-exposure DPOAE level could be used with reasonable confidence to determine if the status of the peripheral auditory system was either normal (PTS $\leq 5 \mathrm{~dB}$ ) or abnormal (PTS $>30 \mathrm{~dB}$ or outer hair cell (OHC) loss $>40 \%)(25)$. Furthermore, changes induced by moderate or severe noise exposure that give rise to temporary threshold shift (TTS) have been shown to alter the amplitude or frequency composition of TEOAEs (11) and DPOAEs $(7,10,25)$, as well as spontaneous otoacoustic emissions (SOAEs) (1). Lucertini et al. showed high sensitivity and specificity of TEOAE as a screening method for the diagnosis of cochlear damage in military recruits (26). Śliwińska-Kowalska et al. confirmed high sensitivity of TEOAE in assessing changes in the cochlea after short exposure to industrial noise (11).

Atias and Bresloff found reduced click-evoked OAE levels for the frequencies of 1, 2, 3 and $4 \mathrm{kHz}$ after noise exposure (10 minutes exposure to white noise at $90 \mathrm{~dB}$ ) in patients with normal audiograms (27). Noise emitted by weapons is especially dangerous because hearing damage can occur almost immediately after a single exposure to a loud impulse (e.g., rifle, grenade). Konopka et al. noticed that 10-15 min after shooting, the TEOAE amplitude reduction was between 3 and $4 \mathrm{kHz}$, particularly in the right ear (9). Otoacoustic emission can be useful to evaluate occupational noise influence on hearing as well as to monitor cochlear functions. Its unparalleled precision in pinpointing noise-damaged areas within the cochlea makes the recording of otoacoustic emissions an important method in the prophylaxis and treatment of noise-induced hearing damage, especially when other methods prove to be insufficiently sensitive.

As for comparing the sensitivity of PTA and DPOAE in monitoring early changes related to noise damage in technical personnel servicing jet engines, the results of our study are not conclusive, because changes were significant in both tests. To determine which test is better, noise-exposed subjects should be monitored longitudinally.

Although the 1st observation in construction workers was promising in respect of higher sensitivity of DPOAE (mainly at $4 \mathrm{kHz}$ ) in monitoring early signs of NIHL, a 10 -year prospective study showed no advantage of this method over the standard audiometry (28). One of the limitations of translating the data is that significant indi- 
vidual otoacoustic emission (OAE) changes do not necessarily follow the same pattern as the group averaged results. Moreover, hearing deterioration might manifest itself in a local enhancement of OAE (29).

Simultaneous exposure to chemical agents increases the detrimental effect that noise has on the human hearing organ $(1,2)$. The examined group was temporarily exposed to chemicals used in aircraft maintenance and service. Thus, further studies are needed to evaluate the impact of co-exposure to jet engine noise and jet fuel on technical staff hearing.

Prolonged exposure to noise can cause oxidative stress in the cochlea, which results in the loss (via apoptotic pathways) of the outer hair cells of the organ of Corti. It has been demonstrated that some antioxidant molecules, for example L-Nacetyl-cysteine (NAC) or d-methionine, can prevent oxidative stress in the inner ear and protect against acoustic trauma $(30,31)$. Kramer et al. (32) reported no significant differences in distortion product otoacustic emissions (DPOAEs) measured in subjects exposed to loud music; participants were given either $900 \mathrm{mg}$ of NAC or placebo $30 \mathrm{~min}$ before exposure. Lorito et al. also reported that the administration of NAC, in a NIHL animal model, significantly reduced the threshold shifts in the treated animals, and that the role played by NAC injection timing was important for $\mathrm{OHC}$ protection; measuring DPOAEs in the treated and control animals revealed that the best protection was observed in the group receiving NAC after noise exposure (33).

\section{CONCLUSIONS}

1. Results of the noise level measurements have shown that technical personnel servicing jet engines (even in the case of a single exposure) are exposed to noise which greatly exceeds the permissible and safe levels, i.e., the maximum admissible intensity (MAI) in the working environment.

2. Despite the usage of hearing protection devices, both PTA and DPOAE consistently showed poorer hearing in the noise-exposed subjects vs. controls. Frequencies affected in cochlea corresponded with the dominant frequency components of noise emitted by jet engines.

3. Further studies are needed to evaluate the impact of co-exposure to jet engine noise and jet fuel on technical staff hearing.

4. Hearing conservation program should be developed for technical personnel servicing jet engines.

\section{REFERENCES}

1. Konopka W, Pawlaczyk-Łuszczyńska M, Straszyński P, Śliwińska-Kowalska M. [Assessment of acoustic environment and its effect on hearing in jet engine servicing personnel]. Med Pr. 2004;55(4):329-35. Polish.

2. Kaufman LR, LeMasters GK, Olsen DM, Succop P. Effects of concurrent noise and jet fuel exposure on hearing loss. J Occup Environ Med. 2005;47(3):212-8, http://dx.doi.org/10.1097/01.jom.0000155710.28289.0e.

3. Kuronen P, Toppila E, Starck J, Pääkkönen R, Sorri MJ. Modeling the risk of noise-induced hearing loss among military pilots. Int J Audiol. 2004;43(2):79-84, http://dx.doi.org/10.1080/14992020400050013.

4. Kryter K, Garinther GR. Auditory effects of acoustic impulses from firearms. Acta Otolaryngol Suppl (Stockh). 1966;211(45):22-5.

5. Salmiviani A. Acoustic trauma in regular army personnel: Clinical audiologic study. Acta Otolaryngol Suppl (Stockh). 1967;222:85-7.

6. Kyong-Myong C, Hwan-Jung R, Eui-Kyung G. Noise induced hearing loss and the individual susceptibility to the noise. Int Tinnitus J. 1996;2:73-82.

7. Harding GW, Bohne BA, Ahmad M. DPOAE level shifts and ABR threshold shifts compared to detailed analysis of histopathological damage from noise. Hear Res. 2002;174(1-2):158-71, http://dx.doi.org/10.1016/S03785955(02)00653-6.

8. Subramaniam M, Salvi RJ, Spongr VP, Henderson D, Powers NL. Changes in distortion product otoacoustic emissions and outer hair cells following interrupted noise exposures. Ear Hear. 1994;15:299-309.

9. Konopka W, Pietkiewicz P, Zalewski P. Evaluation of transient and distortion product otoacoustic emissions before and after shooting practice. Noise Health. 2001;3(10):29-37.

10. Lonsbury-Martin BL, McCoy MJ, Whitehead ML, Martin GK. Clinical testing of distortion-product otoacoustic emissions. Ear Hear. 1993;14(1):11-22, http://dx.doi. org/10.1097/00003446-199302000-00003.

11. Śliwińska-Kowalska M, Kotyło P, Hendler B. Comparing changes in transient-evoked otoacoustic emission and pure-tone audiometry following short exposure to industrial noise. Noise Health. 1999;2:50-7.

12. PN-N-01307:1994. [Noise. Permissible values of noise in the workplace. Requirements relating to measurements]. Warszawa: Polish Committee for Standardization; 1995. Polish.

13. PN-ISO 9612:2004. [Acoustics - Guidelines for the measurement and assessment of exposure to noise in the 
working environment]. Warszawa: Polish Committee for Standardization; 2004. Polish.

14. Yantis PA. Audiology. In: Clieve JV, editor. Galandet encyclopedia of deaf people and deafness. Vol. 1, A-G. New York: McGraw-Hill Book Company Inc.; 1987. p. 40-4.

15. ISO 389:1975. Acoustics - Standard reference zero for calibration of pure-tone audiometers. Geneva: International Organization for Standardization; 1975.

16. ISO 389 ADI. Addendum No. 1 to ISO 389/1975. Geneva: International Organization for Standardization; 1983.

17. [Ordinance issued by Minster of Labour and Social Policy of November 29, 2002 on maximum admissible concentration and maximum admissible intensity values for agents harmful to human health in the work environment, with later amendments]. Off J Laws 2002, No. 217, item 1833. Polish.

18. PN-EN 458:2006. [Hearing protectors - Recommendations for selection, use, care and maintenance - Guidance document]. Warszawa: Polish Committee for Standardization; 2004. Polish.

19. Śliwińska-Kowalska M, Dudarewicz A, Kotyło P, Zamysłowska-Szmytke E, Pawlaczyk-Łuszczyńska M, Gajda-Szadkowska A. Individual susceptibility to noise-induced hearing loss: Choosing an optimal method of retrospective classification of workers into noise-susceptible and noise-resistant groups. Int J Occup Med Environ Health. 2006;19(4): 235-45, http://dx.doi.org/10.2478/v10001-006-0029-2.

20. Jędrzejczak W, Blinowska K, Konopka W. Time-frequency analysis of transiently evoked otoacoustic emissions of subjects expose to noise. Hear Res. 2005;205(1-2):249-55.

21. Sułkowski W, Pawlaczyk-Łuszczyńska M. Evaluation of occupational exposure to noise from hearing conservation point of view. Int J Occup Med Environ Health. 1994;7(2):167-75.

22. Lapsley Miller JA, Marshall L, Heller LM. A longitudinal study of changes in evoked otoacoustic emissions and pure-tone thresholds as measurement in hearing conservation program. Int J Audiol. 2004;43(6):307-22, http://dx.doi.org/10.1080/14992020400050040.

23. Subramaniam M, Henderson D, Spongr V. The relationship among distortion-product otoacoustic emissions, evoked potentials thresholds, and outer hair cells following interrupted noise exposures. Ear Hear. 1994;15(4):299-309, http://dx.doi.org/10.1080/14992020400050040.
24. Eddins AC, Zuskov M, Salvi RJ. Changes in distortion product otoacoustic emissions during prolonged noise exposure. Hear Res. 1999;127(1-2):119-28, http://dx.doi. org/10.1016/S0378-5955(98)00182-8.

25. Davis B, Qiu W, Hamernik RP. The use of distortion product otoacoustic emissions in the estimation of hearing and sensory cell loss in noise-damaged cochleas. Hear Res. 2004;187(1-2):12-24, http://dx.doi.org/10.1016/ S0378-5955(03)00339-3.

26. Lucertini M, Bergamaschi A, Urbani L. Transient evoked otoacoustic emission in occupational medicine as an auditory screening test for employment. Br J Audiol. 1996;30:79-88.

27. Atias J, Bresloff I. Noise induced temporary otoacoustic emission shifts. J Basic Clin Physiol Pharmacol. 1996;7:221-33.

28. Seixas NS, Neitzel R, Stover B, Sheppard L, Feeney P, Mills D, et al. 10-year prospective study of noise exposure and hearing damage among construction workers. Occup Environ Med. 2012;69(9):643-50, http://dx.doi. org/10.1136/oemed-2011-100578.

29. Helleman HW, Dreschler WA. Overall versus individual changes for otoacoustic emissions and audiometry in a noise-exposed cohort. Int J Audiol. 2012;51(5):362-72, http://dx.doi.org/10.3109/14992027.2011.653447.

30. Lorito G, Giordano P, Prosser S, Martini A, Hatzopoulos S. Noise-induced hearing loss: A study on the pharmacological protection in the Sprague Dawley rat with $\mathrm{N}$-acetylcysteine. Acta Otorhinolaryngol Ital. 2006;26(3):133-9.

31. Rewerska A, Pawełczyk M, Rajkowska E, Politański P, Śliwińska-Kowalska M. Evaluating D-methionine dose to attenuate oxidative stress-mediated hearing loss following overexposure to noise. Eur Arch Otorhinolaryngol. 2013;270(4):1513-20, http://dx.doi.org/10.1007/s00405-01 2-2265-3.

32. Kramer S, Dreisbach L, Lockwood J, Baldwin K, Kopke R, Scranton S, et al. Efficacy of the antioxidant $\mathrm{N}$-acetylcysteine (NAC) in protecting ears exposed to loud music. J Am Acad Audiol. 2006;17(4):265-78, http://dx.doi.org/10.3766/jaaa.17.4.5.

33. Lorito G, Giordano P, Petruccelli J, Martini A, Hatzopoulos S. Different strategies in treating noise induced hearing loss with $\mathrm{N}$-acetylcysteine. Med Sci Monit. 2008;14(8):BR159-64.

The use of the article „The influence of jet engine noise on hearing of technical staff” is permitted under license conditions of Creative Commons AttributionNonCommercial 3.0 (also known as CC-BY-NC), available at http://creativecommons.org/licenses/by-nc/3.0/pl/ or another language version of this license or any later version of this license published by Creative Commons / Zezwala się na korzystanie z artykułu „Wpływ hałasu silników odrzutowych na słuch personelu technicznego" na warunkach licencji Creative Commons Uznanie autorstwa - Użycie niekomercyjne 3.0 (znanej również jako CC-BY-NC), dostępnej pod adresem http://creativecommons.org/licenses/by-nc/3.0/pl/ lub innej wersji językowej tej licencji, lub którejkolwiek późniejszej wersji tej licencji, opublikowanej przez organizację Creative Commons. 